\title{
IMPROVING STUDENTS' READING COMPREHENSION OF PROCEDURE TEXTS BY USING COLLABORATIVE STRATEGIC READING
}

\author{
Hermi Suswanti \\ SMP N 2 Ampek Angkek Agam, Indonesia \\ E-mail:wantidodi3@gmail.com \\ Submitted: 25-02-2021
DOI: $\underline{\text { https://doi.org/10.22202/tus.2021.v7i1.4809 }}$
}

\begin{abstract}
There are some text types in school based curriculum 2013. They are description, recount, narrative, procedure, and report. In this research the researcher chooses procedure text. There are some ways to improve the student's reading comprehension of procedure texts. This research aims to find out whether collaborative strategic reading can improve student's reading comprehension of procedure texts. The method of this research was using classroom action research by collecting the data through pretest and posttest and described them into detail explanation. Then they were compared between posttest 1 and posttest 2.The result is the 41,6 in posttest 1 and 65 in post-test 2.It means there is an improvement by using collaborative strategic reading in teaching procedure texts.
\end{abstract}

Keywords: improving reading comprehension, procedure texts, collaborative strategic reading

\section{INTRODUCTION}

Students are expected to have good reading comprehension in order to solve the problem in reading passage. Students are obliged to have skill in identifying all of reading comprehension questions which are based on indicators given in the English National Curriculum for Junior High School. In addition, there is a KKM (Kriteria Ketuntasan Minimal) of the score for English which must be obtained by the students. The minimal KKM for English at grade IX 1 of SMPN 2 Ampek Angkek is 64.

Actually, many students have difficulties in achieving good reading comprehension due to some problems such as: Low interest, poor motivation, poor grammar, and poor reading style, lack of vocabulary, lazy to read and to do the tasks. Beside, the problem came from the teacher's side. Their ways of teaching are monotonous. It leads into passive atmosphere in class. 
Realizing about the role and the contribution of reading at school, the researcher can say that it is very important to stimulate students to fond of reading. From the researcher's preliminary observation at SMPN 2 Ampek Angkek Kabupaten Agam, it is found that many students have problems with reading comprehension. The score found in the report mark recently (75\% students were not fulfilled the criteria of KKM (Kriteria Ketuntasan Minimal). The scores disappoint the students, teachers and parents, because the minimal standard for reading comprehension is 64 . The questions are about finding the general information, getting specific stated information, getting specific unstated information, identifying the generic structures, the language feature, vocabulary/guessing words and communicative purpose of the text. Based on the daily test which was done on January 28, 2021 it showed that most of the students of class IX 1 of SMPN 2 Ampek Angkek got problems in comprehending the procedure texts. As the result, they got difficulties in answering the comprehension questions based on the texts given. They did not understand about how to identify the reading indicators of procedure texts. When the researcher conducted an interview on January 30, 2021, they told that they causes were due to their lack of vocabulary, they do not have good strategy in comprehending the texts, because the teacher explained the lesson too brief and too fast. Furthermore, the uninteresting reading materials lead them into boredom atmosphere.

The discrepancy between the fact and the ideal condition is as the effect of one factor. The teachers only asked the students to read the reading text and answer the reading comprehension questions in the worksheet and students' books individually. Next, the teachers instructed the students who could be able to answer the questions to write their answers on the whiteboard. Finally, the teachers and the students discussed the answers in the classroom together. Low students used to get minor attention. The low and good students could not collaborate together. The collaboration is needed to overcome this phenomenon in the learning process. Then, the researcher conducted a research, classroom action research about how to improve students' reading comprehension of procedure 
texts at SMPN 2 Ampek Angkek Kabupaten Agam. She had chosen the collaborative strategic reading to improve it.

There are some text types in school based curriculum 2013. They are description, recount, narrative, procedure, and report. In this research the researcher chooses procedure text. It is mostly found in daily life. This text is designed to explain how something is achieved through a sequence of actions or steps. It explains how people perform different process in a sequence of works in a good sequence as stated in competence based curriculum. Depdiknas (2004:54) and Depdiknas (2005: 37).

Moreover Derewianka in Depdiknas (2005:3) stated that procedure texts show us how something is done through a serial of actions or steps. There are several social functions of procedure text such as ; giving instruction, giving warning, showing operation guidelines, stating temporal sequence and others. For instruction and warning character sized by imperative as the language feature. For temporal sequencers such as: first, next, then, finally are the characteristic of language feature. Sometimes a text of procedure is added with diagram, flow, chart or illustration, Depdiknas (2005:5). Teachers, in the learning process of reading comprehension, must familiarize the students with all materials above. The materials must be given in an interesting technique in order to make them easy to comprehend.

The materials of procedure texts can be authentic. Procedure text is a text that contains direction, manual, method, or steps in doing something Djuharie (2007:38). Procedure texts contain tips or sequence of action or steps in making or doing something. This kind of texts is also known as director. Procedure texts in general has generic structure as follow: 1) goal, the intention of the activity, 2) List of materials, some things need to make a certain thing or to do a certain activity,3) Series of steps sequenced in logical order. This theory supports that the materials of procedure text can be authentic, because manual for instance can be taken from the authentic material, the manual of "How to Operate the Washing Machine." 
In addition, according to Djuharie (2007:39) procedure text also has linguistic features or lexico grammatical feature such as: imperative; ask someone to do something (cook, fry, cut), action verbs the words related to actions of body and mind (mix, turn) connective of sequence (then, while), and numbering (first, second, third). Then, Gibbon in Herrel (2008 : 34) argued that collaborative strategic reading is very helpful to English language learners when they are reading for getting information. This should be done through teacher modeling, examples and reinforcement of the behavior that demonstrate in group interaction. Collaborative strategic reading provides chance for the students to express their own idea, without shyness, because all of them must show their respect. The various ideas are the characteristic of collaboration. Collaborative strategy is empowering for a group of learner to catch the idea of printed materials. So, the students can collaborate in doing the task of printed material. They do it orally in the form of collaboration in order to avoid boredom, shyness, and passive situation .He added that collaborative reading is a strategy that is helpful to English language learners when they are reading for information. There are many students, which have been observed by the researchers (international, national or local researchers) related to improving students' reading comprehension and collaborative strategic reading in teaching English. They had been successful using this strategy in improving students' English ability. First, Steven and (Lander and Brown 1995)did a research about CIRC. The setting of the research was at the rural areas in Baltimore. The participants were the students of class 2 until 6. They found that there was significant improvement in reading skill. This strategy could be applied for a long period of time (2 years) effectively. This strategy worked effectively both for the low and high level students.

Next, (Slavin 1984) also did a research. The setting of his research was at the schools which were located in town, village and rural areas. The participants were grade III up to grade XII students in towns, villages and rural areas. The research was conducted for 4 until 30 weeks. He found that from 22 researches from class 3 until 12, 17 of them showed significant improvement 
Furthermore, Erni (2008) had also conducted a research Improving Student's Reading Comprehension of Narrative Text by Using Collaborative Reading Strategy at Grade Eight-Three of SMPN 1. This research was conducted in Payakumbuh. The participants of the research were the students of VIII 3 of SMP N 1 Payakumbuh. She found that using collaborative reading strategy could improve the students reading comprehension process of narrative texts.

By considering the related findings above, it can be concluded that collaborative strategic reading can be an alternative way in improving students' English. It was found that there was significant improvement in reading skill.

\section{METHODS}

This classroom action research was conducted at SMPN 2 Ampek Angkek in Balai Gurah. Time allocation for English lesson is $4 \times 40$ minutes in a week (2x40 minutes) for each meeting. This research was done from February 1 until 25,2021 . It was done in two cycles. Each cycle consisted in four meetings (each meeting consist of $2 \times 40$ minutes).

The participants of this research were the first, Hermi Suswanti, researcher herself. The second were class IX 1 students of SMPN 2 Ampek Angkek. There were thirteen girls and eleven boys in this classroom. The last participant was the collaborator of this research. There was another English teacher. She was a senior English teacher, and graduated from Bung Hatta University Padang. Her name was Elmaneli, S.Pd.The instrumentation of the research were; a. The researcher herself was the key instrument of this classroom action research.b.Observation; the observation was held during the teaching and learning activities. To obtain the data through observation, the researcher was helped by collaborator. The data was collected by using several observation checklist related to reading comprehension of procedure texts and collaborative strategic reading. They were used to record and collect real information of teaching and learning process and the performance. There was a checklist while teaching and learning process is ongoing. Checklist was done during the classroom activities. There were three kinds of checklist like; the checklist of indicator of reading comprehension of procedure texts, the 
checklist of indicator of collaborative reading strategy, and the checklist of steps of lesson plan. The researcher also used field notes to report things happened in the teaching and learning process. Field notes were used by researcher and collaborator to record everything about activities that they observe. c. By conducting interview, the researcher understood the reason lied behind certain fact or behavior. d. Video recording. The researcher recorded the activities to get the data in her class during the research. From the record, the researcher could observe the process clearly in order to have complete data. The researcher and collaborator recorded the data.

The instrument of this research was a reading comprehension test. It was in the form of short-answer tests. The numbers of the questions were 20 items. Each correct answer got 5 score. This action research was conducted in two cycles

Firstly, the researcher conducted a reading comprehension test as the placement -test. The purpose was to get the starting point of the student's reading comprehension. Next, the test result was used to group the students based on the characteristic of collaborative reading strategy. The data was collected through reading comprehension test after the cycle 1 , and 2 to find out the student's reading comprehension skill. To avoid subjectivity the researcher needed a collaborator to assist her in doing the test. After collecting the data, the data was analyzed as quantitative and qualitative Form.

\section{FINDING AND DISCUSSION}

To answer the research the research question, this study used three tests namely pretest and posttest. In measuring test results, rubrics are needed so that the results are more valid. The following are checklist of indicator of reading comprehension of procedure texts used to measure the results of research test.

a. The checklist of indicator of reading comprehension of procedure texts

\begin{tabular}{|l|l|l|l|l|}
\hline No & \multicolumn{1}{|c|}{ Indicator } & yes & no & result \\
\hline 1 & $\begin{array}{l}\text { Students can find general } \\
\text { information of the procedure texts }\end{array}$ & & & \\
\hline 2 & $\begin{array}{l}\text { Students can find the specific } \\
\text { stated information of the procedure }\end{array}$ & & & \\
\hline
\end{tabular}




\begin{tabular}{|l|l|l|l|l|}
\hline & texts & & & \\
\hline 3 & $\begin{array}{l}\text { Students can Find the specific } \\
\text { unstated information of the } \\
\text { procedure text }\end{array}$ & & & \\
\hline 4 & $\begin{array}{l}\text { Students can identify the language } \\
\text { feature of the procedure texts }\end{array}$ & & & \\
\hline 5 & $\begin{array}{l}\text { Students can Find the social } \\
\text { function of the procedure texts }\end{array}$ & & & \\
\hline 6 & $\begin{array}{l}\text { Students can identify the generic } \\
\text { structure identify the }\end{array}$ & & & \\
\hline .7 & $\begin{array}{l}\text { Students can } \\
\text { vocabulary/guessing words }\end{array}$ & & \\
\hline
\end{tabular}

b. The check list of indicators of collaborative strategic reading. It was designed as on the following:

\begin{tabular}{|c|c|c|c|c|}
\hline No & Indicator & Yes & No & Result \\
\hline 1 & $\begin{array}{l}\text { students can overcome their shyness by } \\
\text { working collaboratively }\end{array}$ & & & \\
\hline 2 & $\begin{array}{l}\text { Students show their respects toward } \\
\text { different ideas each other }\end{array}$ & & & \\
\hline 3 & $\begin{array}{l}\text { students ' } \text { self-confidence increase } \\
\text { during collaboration }\end{array}$ & & & \\
\hline 4 & $\begin{array}{l}\text { students interact actively to ask } \\
\text { questions, share ideas and find the } \\
\text { answers of the texts in their group }\end{array}$ & & & \\
\hline 5 & $\begin{array}{l}\text { Each member of the group participate } \\
\text { (speaks) during the presentation of their } \\
\text { group. }\end{array}$ & & & \\
\hline
\end{tabular}

Mean of students' reading comprehension skill of procedure texts before the research (Placement -Test)

\begin{tabular}{|c|c|c|c|c|c|c|c|c|c|c|}
\hline \multicolumn{9}{|c|}{ Reading comprehension indicators of procedure texts } & \multirow{2}{*}{ Score } & \multirow{2}{*}{ Quality } \\
\hline $\begin{array}{l}\text { Students } \\
\text { no }\end{array}$ & I 1 (3) & I2 (5) & $\mathrm{I} 3(5)$ & $\mathrm{I} 4(3)$ & I5 ( 1$)$ & I6 (1) & I7 (2) & Total & & \\
\hline 1 & 0 & 1 & 0 & 0 & 0 & 0 & 0 & 1 & 5 & poor \\
\hline 2 & 1 & 2 & 3 & 3 & 1 & 1 & 1 & 12 & 60 & good \\
\hline 3 & 1 & 5 & 0 & 0 & 1 & 1 & 2 & 10 & 50 & fair \\
\hline 4 & 0 & 0 & 0 & 0 & 1 & 1 & 0 & 12 & 60 & good \\
\hline 5 & 0 & 4 & 1 & 1 & 1 & 0 & 0 & 7 & 35 & poor \\
\hline 6 & 0 & 0 & 0 & 0 & 0 & 0 & 0 & 0 & 0 & poor \\
\hline 7 & 1 & 1 & 1 & 0 & 1 & 1 & 1 & 6 & 30 & poor \\
\hline 8 & 1 & 5 & 3 & 1 & 1 & 0 & 1 & 12 & 55 & fair \\
\hline
\end{tabular}




\begin{tabular}{|l|c|c|c|c|c|c|c|c|c|c|}
9 & 0 & 0 & 0 & 0 & 0 & 0 & 0 & 0 & 0 & poor \\
\hline 10 & 1 & 3 & 0 & 0 & 0 & 0 & 0 & 4 & 20 & poor \\
\hline 11 & 1 & 4 & 0 & 0 & 0 & 0 & 0 & 5 & 25 & poor \\
\hline 12 & 2 & 3 & 0 & 0 & 0 & 0 & 0 & 5 & 25 & poor \\
\hline 13 & 2 & 1 & 2 & 0 & 0 & 0 & 0 & 5 & 25 & poor \\
\hline 14 & 1 & 5 & 2 & 1 & 1 & 1 & 1 & 12 & 60 & good \\
\hline 15 & 0 & 4 & 1 & 1 & 1 & 1 & 1 & 9 & 45 & poor \\
\hline 16 & 1 & 5 & 1 & 2 & 1 & 1 & 1 & 12 & 60 & good \\
\hline 17 & 1 & 1 & 0 & 0 & 0 & 0 & 0 & 2 & 10 & poor \\
\hline 18 & 2 & 6 & 3 & 2 & 1 & 0 & 1 & 14 & 70 & good \\
\hline 19 & 1 & 2 & 0 & & 0 & 0 & 0 & 3 & 15 & poor \\
\hline 20 & 1 & 3 & 1 & 0 & 1 & 0 & 0 & 6 & 30 & poor \\
\hline 21 & 1 & 3 & 0 & 0 & 0 & 0 & 0 & 4 & 20 & poor \\
\hline 22 & 1 & 1 & 0 & 0 & 0 & 0 & 0 & 2 & 10 & poor \\
\hline 23 & 1 & 1 & 3 & 0 & 0 & 0 & 0 & 5 & 25 & poor \\
\hline 24 & 0 & 2 & 5 & 3 & 1 & 1 & 1 & 13 & 65 & good \\
\hline total & 20 & 62 & 26 & 15 & 12 & 8 & 10 & 161 & 800 & \\
\hline mean & 0.83 & 2.58 & 1.08 & 0.6 & 0.5 & 0.3 & 0.41 & 6.7 & 33.3 & \\
\hline
\end{tabular}

\section{Annotation:}

$\mathrm{I} 1=$ finding the general information of the texts

$\mathrm{I} 2=$ finding the specific stated information of the texts

$\mathrm{I} 3=$ finding the specific unstated information of the texts

I4= Identifying the language feature of the texts

I5= identifying the social function of the texts

I6= identifying the generic structure of the texts

I7 = finding the vocabulary/guessing words of the texts

This section presents the findings and discussion of the research. This research was divided into two cycles. There were four steps for each cycle. The steps were plan, action, observation, and reflection. Before doing the first cycle, the researcher held placement-test to the students.

Based on the data analysis done during the two cycles, the researcher found that applying collaborative strategic reading in reading comprehension skill of procedure texts could improve the students' reading comprehension skill of procedure texts. It was supported from the results of the students' reading 
comprehension skill test at the end of each cycle, the observation sheets and field notes, and the interview. The description can be seen from the data analysis both quantitatively and qualitatively during the two cycles.

There were some indicators of reading comprehension of placement test on the following:1) Finding general information, 2) finding specific stated information, 3) Finding specific unstated information, 4) Finding the language feature, 5)Finding the social function , 6) Finding the Vocabulary or guessing word. In this research the researcher used the procedure texts materials such as; How to Make Fried Noodle with Dumpling, How to print a paper, Rosa's Sprinkle Sweet Banana, and How to make a pencil case. The score of the placement - test was got by using the formula of mean suggested by (Gay, L., Mills, G., \& Airasian 2006)

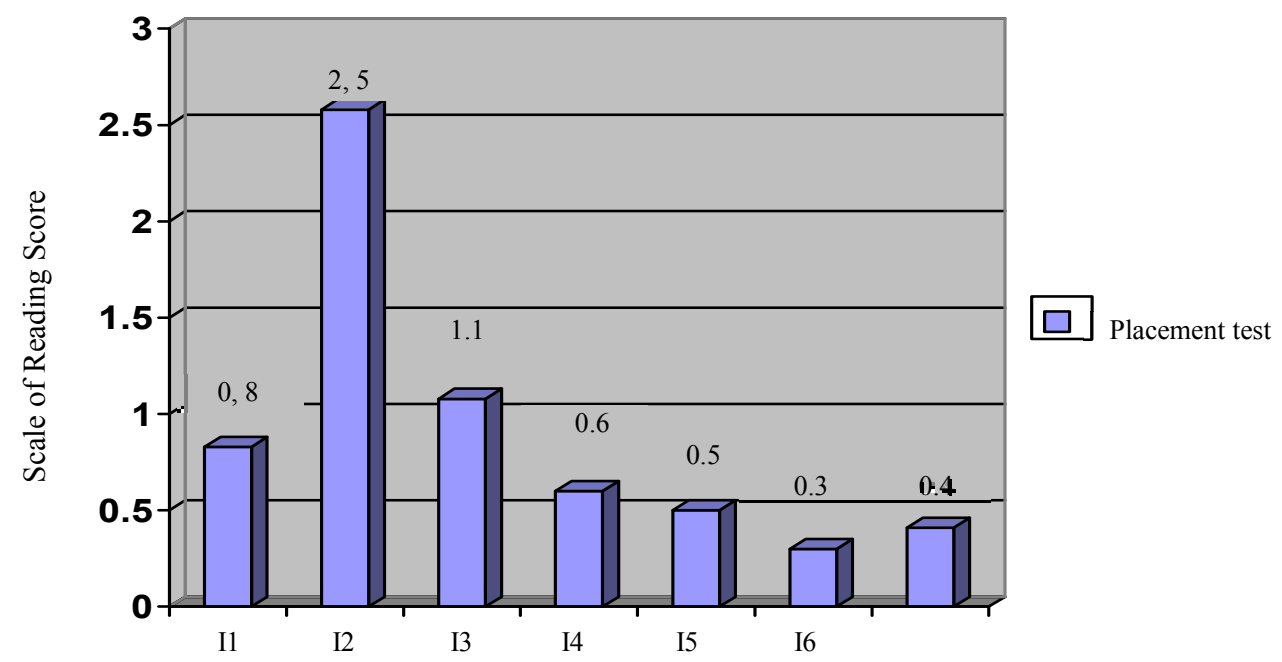

Figure 1: Mean of Students' Reading Comprehension of Procedure Text Skill after placement test

Annotation:

I1 = finding the general information of the texts

$\mathrm{I} 2=$ finding the specific stated information of the texts

$\mathrm{I} 3=$ finding the specific unstated information of the texts

I4= Identifying the language feature of the texts

I5= identifying the social function of the text 
I6= identifying the generic structure of the text

$\mathrm{I} 7=$ finding the vocabulary/guessing words of the texts

The mean of students' score in the test was 32. It shows that the students' mean score was very low. The students' mastery of all component of reading comprehension of procedure texts was very low also. Based on the minimal competency standard of reading skills at class IX 1 of SMPN 2 Ampek Angkek, the students' score should be more than or the same as 64.In order to fulfill its competency standard of reading comprehension of procedure texts the researcher decided to prepare the cycle 1 by considering the students' problems in reading comprehension of procedure texts.

The implementation of this action research in the cycle 1 was done in four meetings. It started on February 1, 4, 9 and 11 2021. Before conducting the research, the researcher prepared some plans which were done in the action phase. In this stage, the students implemented collaborative strategic reading strategy. They were divided into group of four. They collaborated in their group first, and then they shared their works in whole class. For the first meeting, the researcher opened the class by greeting the students and giving motivation. Then, the researcher gave motivation by asking their condition. The researcher also asked them about their breakfast that morning in order to lead them to the materials.

The researcher asked the students to brainstorm each title, in order to introduce them to the topic. The researcher demonstrated some action for verbs used in each text. The researcher also presented the real object used such as; to relieve asthma (a puffer) for the texts breathing difficulties asthma. Just by chance, the collaborator suffered from asthma and used to carry the puffer wherever he went. The students looked enthusiastic while the researcher demonstrated the actions of the verbs used and also when the researcher introduced the noun by pointing to the real objects. Then, the researcher made some notes of the vocabulary on the white board and asked the students to copy it in their note books. This note could help the students in doing their task by using collaborative reading strategy in their groups. Furthermore, the researcher also used the texts for exploiting the generic structure of the texts. She taught the 
students about the title, materials and the steps. Next, she guided the students to find out the language feature of the procedure texts. In this case, she guided the students to pay attention to the tense use. The tense used in procedure texts is simple present tense. Then, she explained about imperative and ordinal numbers. Imperative such as; mix the ingredients, stir it well and ordinal numbers such as; first, second, next are also the lexico grammatical feature of the procedure texts. Without understanding the generic structure and lexico grammatical of procedure texts well, it is hard for the students to comprehend texts fully.

The researcher divided the students into group of six based on the result of their placement-test. Each group consisted of students from different level. Each group had one student who was good in reading and writing. The good students could be the leader in their group and helped their low friends during the discussion. Each group got different texts but still for the same aspects of reading.

For the first meeting the class was very noisy. Many students moved to join their group by bringing their own chairs and tables also. The researcher asked them to join their group just by bringing their bags. At first, they did not agree, because they just felt comfortable if they sat on their own chairs and wrote on their own tables. The researcher tried to manage the class by saying that the students just sat on their friend's chair where they supposed to sit. The researcher reminded them if they brought their own chair and table, it would take much time and energy, because they had to return them back to the basic position. At last they listened to the researcher instruction and joined their group by sitting on their friend's chair and used their friends' tables. The collaborator told the researcher that the students preferred their own chairs and tables due to the conditions of the chairs and the tables themselves. There were $60 \%$ tables and chairs were not in good condition. There were many small holes on the table so the students could not write well. There were also many broken chairs so they could not sit comfortably. Then, the students started working in their group in order to discuss their text more deeply. But there were still many students looked confused about the steps of doing collaborative reading strategy. They asked the teacher from their group so many times. It made the class so noisy. The researcher calmed 
down the situation by saying that they had to ask questions in turns. The researcher came closer to each group to answer the group's questions and explained the answer more slowly. Most of the time during the first meeting was for questions and answering about collaborative reading strategy steps and the indicators of the procedure texts.

After that they were asked to create eight questions and provide the answers as well about their text. Only few students (about $20 \%$ ) followed the discussion seriously, many of them about ( $80 \%$ ), especially the low students went around the class.

Then, the students started working in their group in order to discuss their text more deeply. But there were still many students looked confused about the steps of doing collaborative reading strategy. They asked the teacher from their group so many times. It made the class so noisy. The researcher calmed down the situation by saying that they must ask questions in turns. The researcher came closer to each group to answer the group's questions and explained the answer more slowly.

At the third meeting, the researcher explained about the steps of collaborative strategic reading, went to each group again and told them that each member of the group had to involve in the collaboration to find the answer of other groups' questions. The purpose of this activity was to increase the students' comprehension of the procedure texts indicators

Then, each group was invited to present their result in turns. It was started from the group 1, 2,3,4,5 and 6. Each member of the group contributed in the discussion. Each member had to take responsibility for the part which they explained. Many of the students were still shy to talk in front of the class in presenting their part. They also got problems in opening, continuing and closing the discussion. After the presentation of each group, there were questions, comments and suggestion from audience stage. Only the high level students enthusiastically participated in giving comment and suggestion. Otherwise, most of the students looked tense, and did the presentation unsatisfactorily. 
To know the extent to which collaborative reading strategy can improve the students' reading comprehension of procedure texts the researcher also held test for cycle 1.The cycle one was done for four meetings. Each meeting consisted of 80 minutes ( $2 \times 40$ minutes). The result of the students 'reading comprehension indicators of procedure texts was not really good.

Mean of Students' Reading comprehension of Procedure Texts Test after Cycle 1

\begin{tabular}{|c|c|c|c|c|c|c|c|c|c|c|}
\hline \multicolumn{9}{|c|}{ Reading comprehension of procedure texts indicators } & \multirow[b]{2}{*}{ Score } & \multirow[b]{2}{*}{ Quality } \\
\hline $\begin{array}{l}\text { Students } \\
\text { no }\end{array}$ & I1 (3) & I2 (6) & I3 (7) & $\begin{array}{l}\text { I4 } \\
(1)\end{array}$ & I5 (1) & I6 (1) & I7 (1) & Total & & \\
\hline 1 & 2 & 1 & 3 & 1 & 0 & 0 & 0 & 7 & 35 & poor \\
\hline 2 & 3 & 5 & 7 & 0 & 1 & 0 & 1 & 17 & 85 & excellent \\
\hline 3 & 0 & 6 & 0 & 1 & 0 & 1 & 1 & 9 & 40 & poor \\
\hline 4 & 1 & 0 & 0 & 1 & 1 & 0 & 0 & 3 & 5 & poor \\
\hline 5 & 2 & 1 & 1 & 1 & 1 & 1 & 1 & 8 & 25 & poor \\
\hline 6 & 2 & 2 & 0 & 1 & 0 & 0 & 0 & 5 & 20 & poor \\
\hline 7 & 2 & 1 & 0 & 0 & 0 & 1 & 0 & 4 & 15 & poor \\
\hline 8 & 2 & 4 & 4 & 1 & 0 & 1 & 1 & 13 & 60 & good \\
\hline 9 & 1 & 2 & 2 & 0 & 1 & 1 & 0 & 7 & 25 & poor \\
\hline 10 & 2 & 2 & 3 & 1 & 1 & 0 & 1 & 10 & 50 & fair \\
\hline 11 & 3 & 2 & 5 & 0 & 1 & 1 & 0 & 12 & 50 & fair \\
\hline 12 & 2 & 3 & 0 & 1 & 1 & 1 & 0 & 8 & 25 & poor \\
\hline 13 & 1 & 0 & 4 & 0 & 1 & 1 & 0 & 7 & 35 & poor \\
\hline 14 & 2 & 4 & 6 & 1 & 1 & 0 & 0 & 14 & 65 & good \\
\hline 15 & 2 & 2 & 3 & 1 & 0 & 1 & 1 & 10 & 45 & poor \\
\hline 16 & 3 & 4 & 7 & 1 & 1 & 0 & 1 & 17 & 80 & excellent \\
\hline 17 & 2 & 2 & 0 & 1 & 0 & 0 & 0 & 5 & 20 & poor \\
\hline 18 & 3 & 5 & 6 & 1 & 1 & 1 & 1 & 18 & 90 & excellent \\
\hline 19 & 3 & 3 & 0 & 1 & 0 & 0 & 0 & 7 & 30 & poor \\
\hline 20 & 1 & 3 & 1 & 0 & 1 & 0 & 0 & 6 & 30 & poor \\
\hline 21 & 2 & 1 & 1 & 1 & 1 & 0 & 1 & 7 & 25 & poor \\
\hline 22 & 2 & 1 & 1 & 1 & 0 & 0 & 1 & 6 & 30 & poor \\
\hline 23 & 2 & 4 & 1 & 1 & 0 & 0 & 1 & 9 & 40 & poor \\
\hline 24 & 2 & 4 & 7 & 1 & 1 & 0 & 0 & 15 & 75 & excellent \\
\hline total & 47 & 62 & 62 & 18 & 14 & 10 & 11 & 217 & 1000 & \\
\hline mean & 1.95 & 2.58 & 2.58 & 0.75 & 0.58 & 0.41 & 0.4 & 9.3 & 41.6 & \\
\hline
\end{tabular}




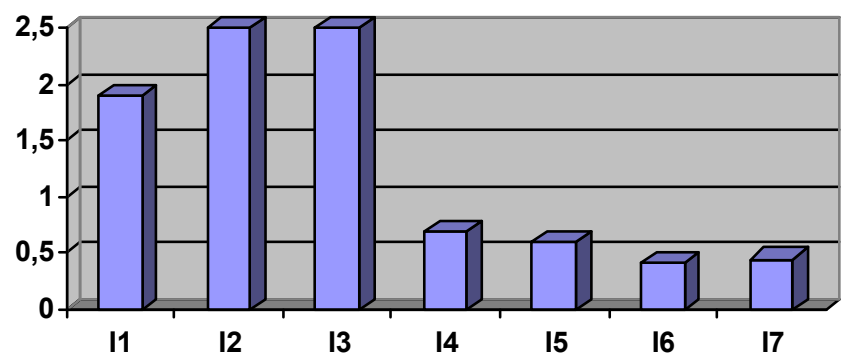

$\square$ The mean of Cycle 1

Figure 2 :Mean of Students' Reading Comprehension of Procedure Text Skill after Cycle1

There were also the mean comparisons of reading indicators in placementtest and in cycle 1

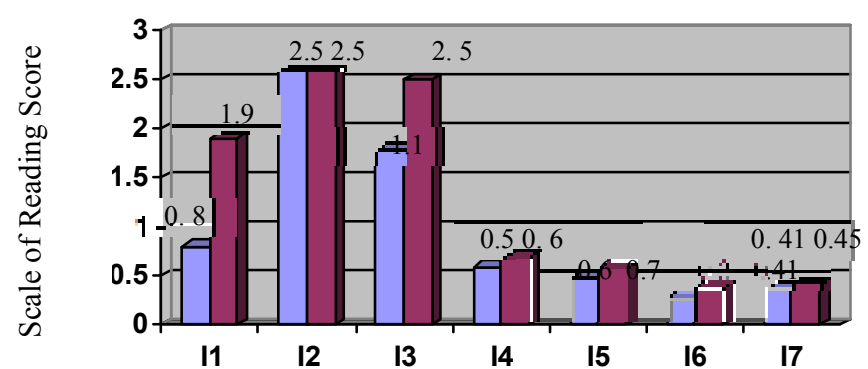

$\square$ The mean of placement test

$\square$ The mean of cycle 1

Figure 3: The Comparison of Students' Mean in Reading Indicators in Placement-test and Cycle 1

The mean of students' score in the cycle 1 was 42 . The data showed that the students' reading comprehension of procedure texts was improved. The mean was improved for 9, 1 points from the placement-test.

Based on the data collected from the field notes, evaluation, and the researcher's experience in doing the action, it can be concluded that the process of teaching and learning by using collaborative strategic reading had not run well yet. 
To conduct the second cycle of this classroom action research, the researcher redesigned her lesson plan for four meetings, three meetings for activities and one meeting for the test. It was done on February 15, 18, 22 and 25, 2021She prepared six texts for cycle two. They were Crisp Roast Duck, The Basic Operation of Digital Camera, How to make a short message service through cell phone, Epe Banana, How to Make a Boat or a Hat and Wet Air. At the first meeting of cycle 2, the researcher explained again about collaborative strategic reading to the students. There were about $55 \%$ students were still uncertain about the process of it. They asked the teacher again. At the second meeting, the process of teaching and learning by using collaborative strategic reading was getting better. When the third meeting came, the students could do the presentation more confidently. They sticked their presentation on a white board and wall in front of the class. They could open, continue and close the presentation well. At the fourth meeting, it was the meeting for conducting the test for cycle 2, the class was quite. The students were much more confident in doing the test. The teacher gave them 80 minutes to finish the test. They could finish the test on time. Nobody asked for additional time. In contrast, they could not finish the task on time at the test for cycle 1 and most of them asked for additional time.

After conducting the collaborative strategic reading for four meetings, the researcher discussed with the collaborator. The collaborator commented the collaborative strategic reading was getting better to improve the students' strategy in learning

At the end of cycle 2 there were 4 texts for the test. They were: A Photo Fish Fun Frame, Keeping fit, Tomato soup, and How to Remove the Ink Stain from the Clothes. There were 20 comprehension questions. Each test had 5 questions.

mean of students reading comprehension skill of procedure texts after cycle 2 


\begin{tabular}{|c|c|c|c|c|c|c|c|c|c|c|}
\hline \multicolumn{9}{|c|}{ Reading comprehension of procedure texts indicators } & \multirow[b]{2}{*}{ Score } & \multirow[b]{2}{*}{ Quality } \\
\hline $\begin{array}{c}\text { Students } \\
\text { no }\end{array}$ & I1 (3) & I2 (5) & I3 (5) & I4(2) & $\begin{array}{c}\text { I5 ( } 1 \\
\text { ) }\end{array}$ & I6 (2) & I7 (2) & Total & & \\
\hline 1 & 2 & 2 & 2 & 2 & 0 & 1 & 2 & 11 & 55 & fair \\
\hline 2 & 3 & 5 & 4 & 2 & 1 & 2 & 2 & 19 & 95 & excellent \\
\hline 3 & 3 & 5 & 4 & 2 & 1 & 2 & 1 & 19 & 95 & excellent \\
\hline 4 & 1 & 2 & 4 & 2 & 1 & 2 & 1 & 13 & 65 & good \\
\hline 5 & 3 & 0 & 4 & 1 & 1 & 0 & 1 & 10 & 50 & fair \\
\hline 6 & 3 & 1 & 4 & 1 & 0 & 0 & 0 & 9 & 45 & poor \\
\hline 7 & 3 & 2 & 5 & 1 & 1 & 1 & 1 & 14 & 70 & good \\
\hline 8 & 3 & 5 & 5 & 1 & 1 & 2 & 1 & 19 & 95 & excellent \\
\hline 9 & 2 & 3 & 0 & 1 & 1 & 2 & 1 & 6 & 30 & poor \\
\hline 10 & 3 & 3 & 4 & 0 & 1 & 0 & 0 & 11 & 55 & poor \\
\hline 11 & 2 & 5 & 4 & 0 & 1 & 1 & 1 & 14 & 70 & good \\
\hline 12 & 3 & 3 & 4 & 2 & 1 & 2 & 2 & 17 & 85 & excellent \\
\hline 13 & 3 & 2 & 5 & 0 & 0 & 0 & 0 & 10 & 50 & fair \\
\hline 14 & 3 & 3 & 4 & 1 & 0 & 1 & 1 & 13 & 65 & good \\
\hline 15 & 3 & 4 & 2 & 1 & 1 & 1 & 1 & 13 & 65 & good \\
\hline 16 & 3 & 4 & 4 & 2 & 1 & 2 & 2 & 18 & 90 & excellent \\
\hline 17 & 1 & 2 & 4 & 2 & 1 & 1 & 1 & 12 & 60 & good \\
\hline 18 & 3 & 2 & 4 & 2 & 1 & 2 & 2 & 20 & 100 & excellent \\
\hline 19 & 3 & 4 & 3 & 1 & 1 & 0 & 0 & 12 & 60 & good \\
\hline 20 & 3 & 4 & 3 & 1 & 0 & 0 & 0 & 11 & 55 & poor \\
\hline 21 & 3 & 3 & 0 & 0 & 1 & 0 & 0 & 7 & 35 & poor \\
\hline 22 & 3 & 3 & 0 & 0 & 1 & 1 & 1 & 9 & 45 & poor \\
\hline 23 & 3 & 0 & 0 & 1 & 1 & 2 & 2 & 11 & 55 & poor \\
\hline 24 & 3 & 1 & 5 & 2 & 1 & 2 & 0 & 14 & 70 & good \\
\hline total & 65 & 68 & 78 & 28 & 19 & 27 & 23 & 312 & 1560 & \\
\hline mean & 2.7 & 2.8 & 3.25 & 1.16 & 0.79 & 1.1 & 0.9 & 13 & 65 & \\
\hline
\end{tabular}




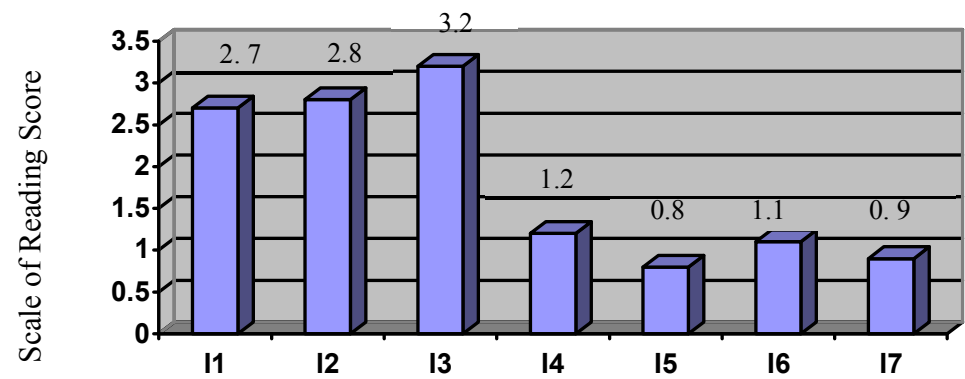

figure 4:Mean of Students' Reading Comprehension of Procedure Text Skill after Cycle

The data above showed that the students' mean of reading comprehension skill of procedure texts at every component were improved

The improvement of the students' reading comprehension of procedure texts from cycle 1 to cycle 2 was 24 that were from 42 to 66 . That calculation indicated the result of reading comprehension of procedure texts in cycle 2 increased significantly, because the minimal standard of competency for reading comprehension of procedure texts was 64 .

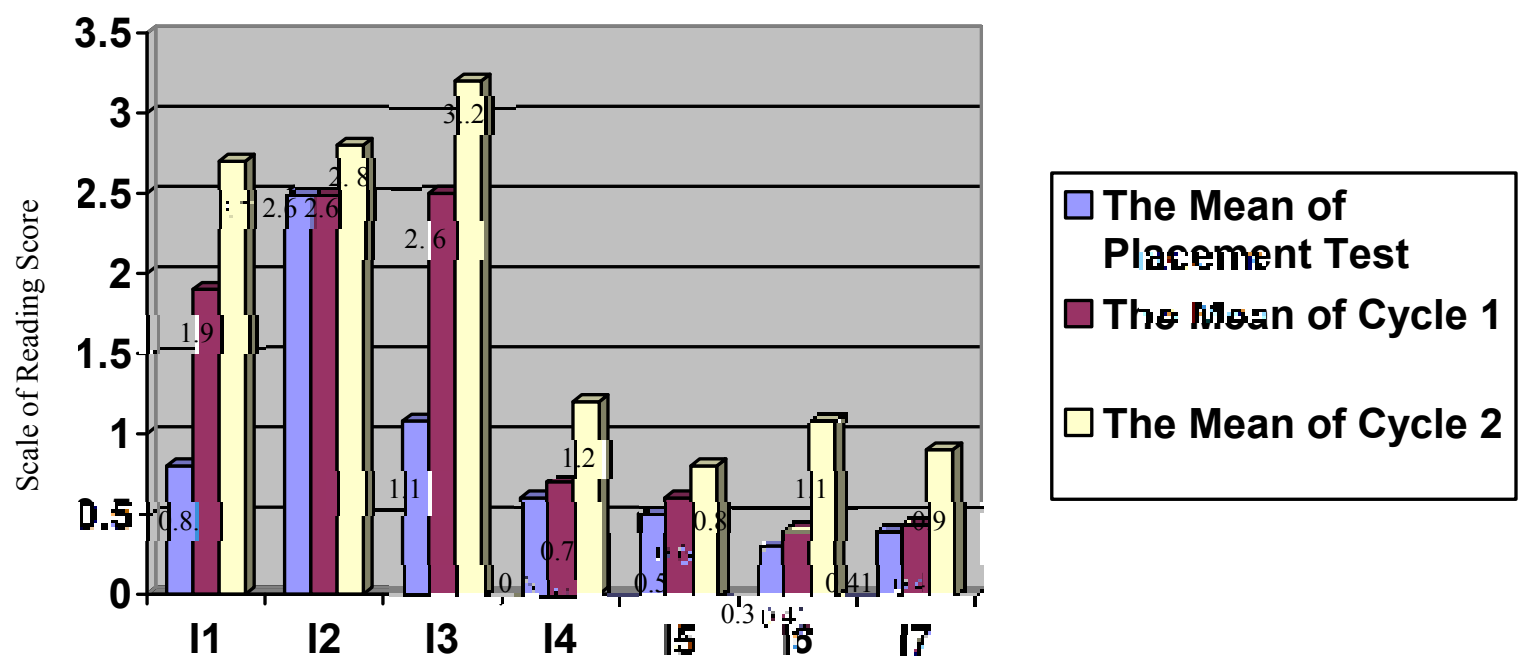

Figure 5 : The comparison of Placement-test, Cycle 1 and Cycle 2 


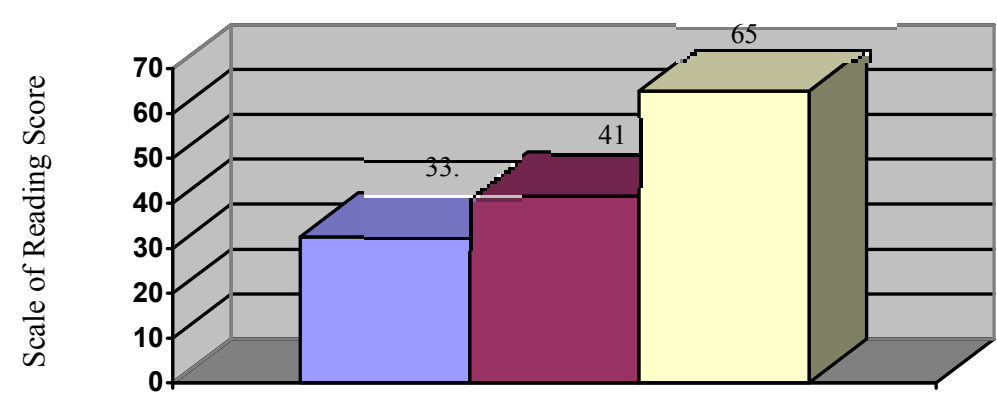

Figure 6 : The comparison of Students' Mean Score in Placement-test, Cycle 1 and Cycle 2

The improvement of the students' reading comprehension of procedure texts from cycle 1 to cycle 2 was 23,8 , that was from 41,6 to 65,4 . That calculation indicated the result of reading comprehension of procedure texts in cycle 2 increased significantly, because the minimal standard of competency for reading comprehension of procedure texts was 64 .

The data got in Mean of students' reading comprehension skill of procedure texts before the research showed poor result. The students' mean score of reading comprehension of procedure texts for each indicator were poor. The mean of students' mean score in the placement-test was 32. The means of students' score in the cycle 1 was 42 . The data showed that the students' reading comprehension of procedure texts was improved. The mean was improved for 9,1 points from the placement-test. The presentation and the feedback from the teacher at the third meeting gave improvement to the students' skill in understanding the indicators of reading comprehension of procedure texts. They were only few students (about 40\%) nervous during the test. The improvement of the result of reading comprehension test from cycle 1 to cycle 2 was 23,8 .

Based on the application of the research and findings of the two cycles, researcher and the collaborator analyzed the data which had been gathered during the cycles and then concluded the causes and effects of the problem. Based on the data from the test, the result of interview, field notes, observation, photographs, 
video recording, and the researcher found that the Findings support the theory of who said that collaborative strategic reading had been proven to be very helpful strategy used in getting information.

The researcher conducted the materials given to the students by creating better strategy that is collaborative strategic reading. This strategy was effective to assist the students' difficulties in comprehending procedure texts. They had more time to think, built their self-confidence, and shared before coming to the presentation. Based on the interview, field notes, video recording and photos took during the teaching and learning process, about $80 \%$ students enjoyed the process of teaching and learning of reading comprehension of procedure texts by using collaborative reading strategy. They looked more serious, more confident and more tolerate. The collaborative strategic reading improved the students' reading comprehension skill of procedure texts successfully. The mean of students' reading comprehension of procedure text was improved significantly.

\section{CONCLUSION}

As the conclusion, the result of the study in cycle 1 , and cycle 2 revealed that the implementation of collaborative strategic reading in teaching reading comprehension of procedure texts was effective in improving the students' reading comprehension skill itself. The improvement of the result of reading comprehension test from cycle 1 to cycle 2 was 23 . Moreover, students were active in the classroom using the collaborative strategic reading in terms of sharing ideas. And the students' opinion about collaborative strategic reading was really positive based on the result of interview after each cycle.

There were some factors influencing the changes of students' reading comprehension of procedure texts by using collaborative strategic reading. Being tolerate could help the students to reduce problem of the eagerness to always get the turns for answering the reading comprehension questions for the good students. In contrast it reduced anxiety for the low students to be asked to answer the reading comprehension questions individually. It made every student responsible for themselves and did not depend on the strong students only because 
at the end of the discussion each member of the group must present their part. It supports the theory proposed by (Brown 2000) He expressed that group work promotes learners' responsibility and autonomy. Discussing in the group could improve the student's self-confidence, in answering the reading comprehension questions, because they had discussed it before the presentation time. Sharing in the whole could enrich students' ideas. It also improved their speaking, listening, and writing. It is in line with the theory proposed by (Slavin 1984) who says that collaborative strategic reading is used for acquisition of language basic skills. Interesting materials, suitable media, good classroom management, teacher approach the factors which could improve the students' reading comprehension of procedure texts. It is in line with the theory proposed by Kustaryo (1998) who says that teacher' s skill and personality influenced the reading comprehension result. (Lander and Brown 1995)

\section{REFERENCES}

Brown, H. Douglas. 2000. “04. Teaching By Principles.” Teaching by Principles: An Intéractive Approach to Language Pedagogy.

Depdiknas . 2007 Panduan Pelaksanaan Classroom Action Research. Jakarta:Depdiknas.

Depdiknas. 2005. Penilaian Pembelajaran Bahasa Inggris. Jakarta: Depdiknas

Depdiknas.2005. Bahasa Inggris. Jakarta: Depdiknas

Depdiknas. 2004. Kurikulum 2004 .Jakarta: Depdiknas

Djuharie, Otong Setiawan. 2007. Genre. Bandung: Yrama Widya.

Gay, L., Mills, G., \& Airasian, P. 2006. "Educational Research- Competencies for Analysis and Applications (8th Edition)." Upper Saddler River, New Jersey: Pearson Education Inc.

Herrel.Addrienne L. 2008. Fifty Strategies for Teaching English Language Learners. Ohio: Prentice Hall.

Kustaryo, Sukirah.1988. Reading Techniques for College Students. Jakarta: P2LPTK. 
Lander, James A., and H. Douglas Brown. 1995. "Teaching by Principles: An Interactive Approach to Language Pedagogy." Language 71(4). doi: $10.2307 / 415773$.

Slavin, Robert E. 1984. "Team Assisted Individualization: Cooperative Learning and Individualized Instruction in the Mainstreamed Classroom." Remedial and Special Education 5(6). doi: 10.1177/074193258400500606.

Yasin, Anas. 2010. Penelitian Tindakan Kelas: Tuntunan Praktis. Padang : Suka Bina Press.

Zainil. 2008. Classroom Action Research. Padang: Suka Bina Offset. 